\title{
Comparison of site effect values obtained by HVSR and HVSRN methods for single-station measurements in Tarnówek, South-Western Poland.
}

\author{
Maciej J. Mendecki, Barbara Bieta, Mateusz Mateuszów, Paweł Suszka \\ Faculty of Earth Science, University of Silesia in Katowice, 60 Bedzinska Str., 41-200, Sosnowiec \\ maciej.mendecki@us.edu.pl
}

Received: $11^{\text {th }}$ November, 2015

Accepted: $22^{\text {th }}$ April, 2016

\begin{abstract}
This study compares the HVSR technique (Horizontal to Vertical Spectral Ratio), based on seismic event records, and the HVSRN technique (Horizontal to Vertical Spectral Ratio of Noise) using seismic noise registrations. Both methods allow us to study the amplification phenomenon of a horizontal component of seismic waves when the waves reach loose sediments in subsurface layers. The seismic data were measured at a three-component single seismic station located in the village of Tarnówek, in the Legnica-Głogów Copper District. The results of the study demonstrate that average HVSRN and HVSR maxima can be distinguished: for periods approximately $3.78 \mathrm{~s}$ $(\mathrm{H} / \mathrm{V}=6.2)$ and $3.969 \mathrm{~s}(\mathrm{H} / \mathrm{V}=8.98)$ respectively. The evaluated share of the Rayleigh wave component in the recorded values was $\beta=0.58$ and it can be suggested that the Love wave share in surface motion was insignificant. The Love wave share remains unknown.
\end{abstract}

Key words: site effects, HVSR, HVSRN, Legnica-Głogów Copper District

\section{Introduction}

Site effects are one of the most important factors used in seismic hazard assessment. They are responsible for a part of damages and failures caused by an earthquake. Due to the occurrence of site effects, it is important to to develop methods for effective investigation of endangered areas so that infrastructure and human lives can be protected. One of the available methods, generally referred to as the HVSR technique (Horizontal to Vertical Spectral Ratio), uses either a spectrum ratio of horizontal to vertical components of ground motion (tremors, coda waves) or ground vibrations (seismic noise). Another empirical method, the HVSRN? technique, also known as the "Nakamura method" (Nakamura 1989) and originally presented in the work Nogoshi \& Igarashi (1971), is the most common approach to assess the site effects (SESAME 2004). The principles of the HVSR method and its applicability have often been presented in numerous publications e.g.: Nakamura (1989), Lermo \& Chavez-Garcia (1993), Bard (1999), Delgado et al. (2000), Bonnefoy-Claudet et al. (2006a and 2006b), Bindi et al. (2008) and (Nakamura 2008).

The aim of this study was to compare both HVSR (of coda waves) and HVSRN (HVSR of Noise) methods. The used data were seismic events and seismic noise recorded at a single station located in the Legnica-Głogów Copper District.

\section{HVSR and HVSRN methods}

As previously outlined, there are two types of $\mathrm{H} / \mathrm{V}$ ratio method, one based on seismic event seismograms (HVSR) and one using 
noise records (HVSRN). However, in many cases both are just referred to as the HVSR technique. In many cases the HVSR method is ambiguously defined and subject to constant change but there are a few main theories explaining how it works assessments made by Nakamura (1989 and 2008), Bard (1999) and Bonnefoy-Claudet et al. (2006a). Depending on the data used the first theory considers the HVSR curves to be a result of S-waves (coda waves) resonating in unconsolidated sediments (Fig.1) with a slight influence of surface waves. The second approach takes into consideration the relationship of the curve with surface waves (mainly Rayleigh waves) which ellipticity is dependent on the natural period/frequency. Maxima marked on HVSR curves are presented in the form of a sharp peak corresponding to the fundamental period/frequency of sediment layer in case when an impedance between hard ground and unconsolidated sediment is clearly manifested (Bard 1999).

Another interesting HVSR curve interpretation can be found in the work of Konno and Ohmachi (1998). They showed that fundamental Rayleigh wave mode relates to HVSR of a microtremor (noise) curve, and they indicated that the curve maximum value corresponds to the transfer function of vertically polarized $\mathrm{S}$-waves and its resonant period (Konno \& Ohmachi 1998; Bard 1999). Many HVSR curves, beside main maxima, contain minima (Fig.2) located in the period bound, which is about half of the value of the period (double value of frequency) corresponding to the maximum peak in the curve. Konno \& Ohmachi (1998) investigated three types of particle orbits during the propagation of fundamental-mode Rayleigh waves. Type 1 appears when the velocity contrast between the two layers is low $(\leq 2.5)$, in which the particle motion is retrograde at any period. Type 2 appears when the contrast is fairly high (velocity ratio of soft and rigid layer is 2.5). With a decrease in the period, the motion changes in variety, and may be retrograde, vertical only, prograde, vertical only, and retrograde. Thus, at both periods $\mathrm{T}_{1}$ and $\mathrm{T}_{2}$ shown in Fig.2, the $\mathrm{H} / \mathrm{V}$ ratio becomes 0 , although $T_{1}$ and $T_{2}$ in type 2 are close to each other. Type 3 appears when the velocity contrast is very high (velocity ratio $\geq 2.5$ ). With decreasing period, particle motion is retrograde, vertical only, prograde, horizontal only, and retrograde. (Konno \& Ohmachi 1998). The construction of HVSR (and HVSRN) curves is mainly used to determine the resonance period of the ground or the amplification coefficient where time consuming and expensive studies are not required (for example studies in the borehole). Furthermore, the HVSR method can carry out measurements on an aseismic area using only seismic noise. An equally valuable aspect of the method is that $a$ priori geological surveying is not necessary (Nakamura 2008).

Presently, it is widely accepted that the HVSR maximum from seismic measurements corresponds to the resonant period of subsurface sediments. However, it is still disputed whether the amplification coefficient might also be determined in this way (Konno \& Ohmachi 1998, Bard 1999, Bonnefoy-Claudet et al. 2006a and 2006b, Atakan 2007, Gosar et al. 2010, Mendecki et al. 2014).

The amplification phenomenon relies on an increase in seismic incident amplitude in a horizontal direction (Fig.1) caused by 
wave transfer from a rigid layer to a soft layer (Bonnefoy-Claudet et al. 2006a and 2006b; Nakamura 2008). The horizontal to vertical amplitude ratio ina rigid layer (for isotropic and homogenic medium) is equal to 1 but in a soft layer, because of occurrence of impedance (different velocities and densities), the horizontal component is enhanced. The HVSR ratio becomes larger than 1 for the resonance period (Fig.1 and 2) but less than 1 (converge to zero) due to the elliptical motion of ground particles and lack of higher Rayleigh waves modes (Konno \& Ohmachi 1998).

\section{Single-station 3C}

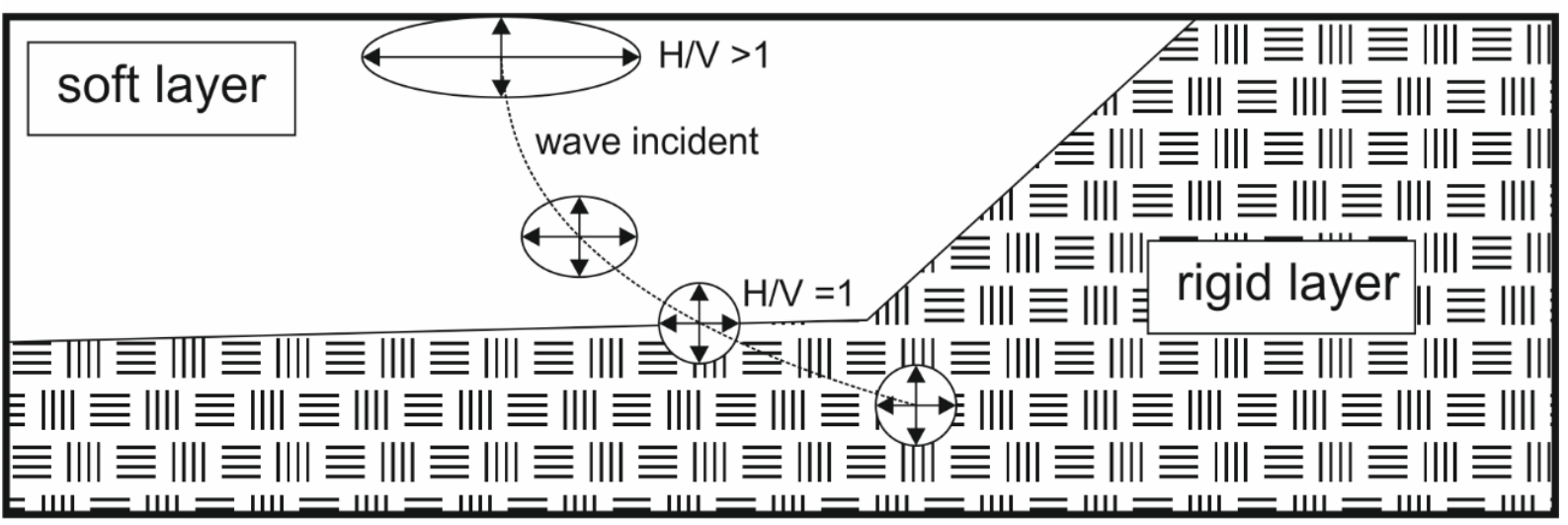

Fig.1. Illustration of amplification phenomenon measured by 3-component (3C) single seismic station located on soft layer sediment.
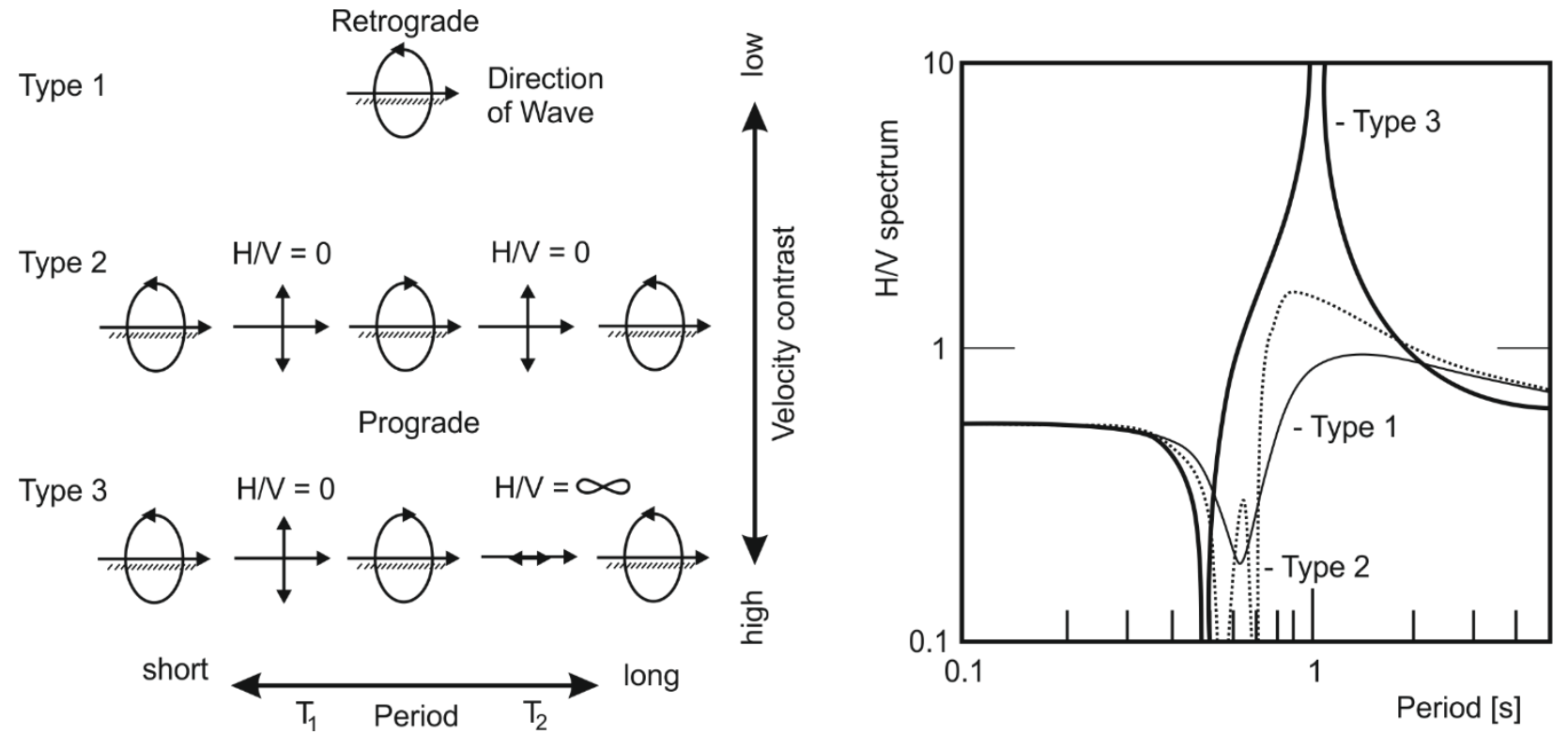

Fig.2. Particle orbit of three types of fundamental-mode Rayleigh waves (left) and three types of H/V ratio of fundamental mode Rayleigh waves (right) (after Konno \& Ohmachi 1998, assumption $\mathrm{T}_{0}=1$ ). 


\section{Site characterization}

The seismic station, from which our data was obtained, is located in Tarnówek village (Fig.3) in the Legnica-Głogów Copper District (LGCD), which is one of the three largest mining basins in Poland. Therefore, it is exposed to the induced tremors caused by copper deposit exploitation. The LGCD is a region located in the For-Sudetes Monocline area in the South-Western part of Poland. The mining of copper ore occurs in the three mines: "Lubin", "Rudna" and "PolkowiceSieroszowice". In this area exploitation is carried out on the floor of the Zechstein rocks plates, which comprise anhydrite and carbonates. The Zechstein rocks are cut by faults and are characterized by compacted and rigid rocks gently dipping in NNE direction (Kazimierczyk 2002). Weak terrigenous Rotliegend sandstones with thicknesses reaching 300 m underly the Zechstein rocks and copper deposits. The Zechstein complex is overlain by Triassic sediments composed of Buntsandstein, Muschelkalk and Keuper (Kazimierczyk 2002).

Due to differences in lithological facies, in the LGCD area a high degree of sediment diversification in subsurface layers is observed. Cenozoic sediments ranged from about $370 \mathrm{~m}$ to $390 \mathrm{~m}$ in thickness (Lubacha 2005, Miller 2005) and comprise gravels, clays, sands and occasionally occurring silts. The gravels are identified as quartz sediments with admixture of sands and clays. The sands are from tens of centimeters to several meters thick and contain a high clay content. Pliocene sediments occur in the form of alternating layers of silts, clays, sands and gravels ranging from $2 \mathrm{~m}-30 \mathrm{~m}$ in thickness. Miocene silts, brown coals and clays, sands and gravels are observed below the Pliocene (Tertiary) layers and this entire complex overlies rigid Mesozoic and Paleozoic rocks. However, the location of the boundary between the soft layer and the consolidated basement cannot be distinguished, but in many cases it is assumed that the boundary lies between the Mesozoic and Cenozoic lithological sequences (Jasinski \& Janicki 2003, Olszewska 2008).

\section{Methodology}

Seismic measurements were collected from a 151B "Observer" seismometer produced by TRIMBLE REFTEK company, a broadband sensor measuring ground vibrations with a frequency range from $0.0083 \mathrm{~Hz}$ to $50 \mathrm{~Hz}$. The seismometer is equipped with three independent sensors (three components) that record motion in three perpendicular directions: vertical, $\mathrm{Z}$, and two horizontal, NS and EW. The sensor possesses a leveling system containing two bubble vials, locking mass knobs and three adjustable feet that allow for the precise positioning of the device. In order to calculate the HVSR and HVSRN curves the J-SESAME program was applied (SESAME 2003; SESAME 2004). This Java operating processing procedure was created as a result of the international project Site EffectS assesment using AMbient Excitations ("SESAME").

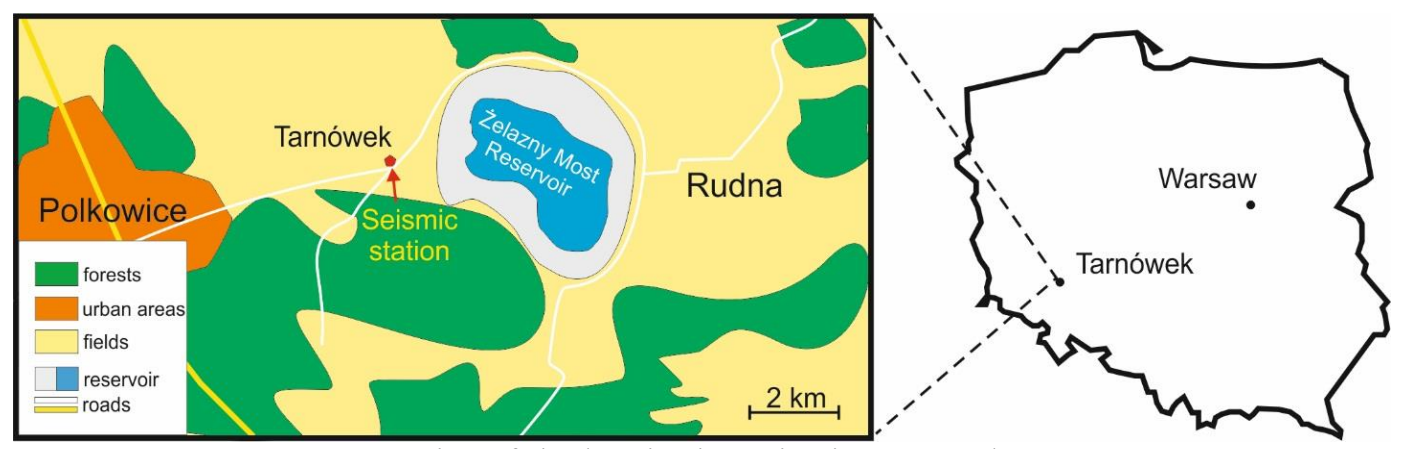

Fig.3. Location of single seismic station in Tarnówek. 
Recommendations for handling and operating the program are contained in the manuals SESAME (2003) and (SESAME) 2004. To analyze HVSR curves all criteria presented in the manuals was taken into consideration. The software possesses the ability to determine the HVSR and HVSRN curves using Fast Fourier Transform (FFT). In addition, the software implements the KonnoOhmachi smoothing function (Konno \& Ohmachi 1998; SESAME 2004).

In order to determine the appropriate HVSR coda waves and HVSR of noise curves, the JSESAME criteria for reliability of results (SESAME 2003; SESAME 2004) were applied. The criteria for a reliable $\mathrm{H} / \mathrm{V}$ curve are as follows:

$f_{0}>10 / I_{w}$ and $n_{c}\left(f_{0}\right)=I_{w} \cdot n_{w} \cdot f_{0}>200$,

where: $I_{w}$ - window length, $n_{w}$ - number of windows selected for the average $\mathrm{H} / \mathrm{V}$ curve, $f_{0}$ - H/V peak frequency.Observing the $\mathrm{H} / \mathrm{V}$ curves, the lowest $f_{0}$ was assumed as 0.2 , thus the $I_{w}=50 \mathrm{~s}$ and $n_{w}=25$. Furthermore, the criteria for a clear $\mathrm{H} / \mathrm{V}$ peak, which are as follows:

i) $\exists f^{-} \in\left[\frac{f_{0}}{4}, f_{0}\right] \mid A_{H / V}\left(f^{-}\right)<\frac{A_{0}}{2}$

ii) $\exists f^{+} \in\left[f_{0}, 4 f_{0}\right] \mid A_{H / V}\left(f^{+}\right)<\frac{A_{0}}{2}$

iii) $A_{0}>2$

iv) $f_{\text {peak }}\left[A_{H / V}(f) \pm \sigma_{A}(f)\right]=f_{0} \pm 5 \%$

v) $\sigma_{f}<\varepsilon\left(f_{0}\right)$ threshold value for

the stability condition

vi) $\sigma_{A}\left(f_{0}\right)<\theta\left(f_{0}\right)$ threshold value for the stability condition

were used to assess the correct interpretation of the peak.
To study the site effects three random events were chosen, that were registered during 201410-26 (Fig.4a), 2014-11-30 (Fig.4b) and 201501-28 (Fig.4c). In addition, one-hour recordings of seismic noise, started at midnight, were chosen from a different set of four days: 201409-07, 2014-11-06, 2014-12-15 and 2015-04-01 and they were applied to evaluate HVSRN curves.

\section{Results}

The application of both techniques allowed us to observe maxima on HVSR and HVSRN curves and their corresponding resonance periods, as well as calculate resonance frequencies.

The average amplification coefficients, produced by ambient seismic noise (Fig.5, Tab.1), was 6.2 at the resonance period $3.78 \mathrm{~s}$ $(0.26 \mathrm{~Hz})$. The results obtained for HVSR curves produced from ambient earthquake records (Fig.5, Tab.2) were similar for the corresponding resonance period obtained in previous dataset (Fig.5, Tab.1), while amplification coefficients increased. According to J-SESAME criteria (equation 1 and 2), the event records yielded an average maximum at the $3.969 \mathrm{~s}$ period $(0.25 \mathrm{~Hz})$ (Fig.5, Tab.2). The average amplification coefficients, shown in Tab.2, reached value 8.96 for the corresponding period. In practice, several peaks can be observed in period band from 0.1 to $1 \mathrm{~s}$, but they do not fulfill the J-SESAME criteria.

As it was mentioned that $\mathrm{H} / \mathrm{V}$ ratios can also contain minima located in the period bound which is half value of period corresponding to the maximum peak in the curve (Konno \& Ohmachi 1998, Bard 1999). Therefore, the obtained $\mathrm{H} / \mathrm{V}$ ratios were investigated in terms of the minima occurrence. Both HVSRN and HVSR curves comprised such minima in averaged periods at $1.45 \mathrm{~s}(0.7 \mathrm{~Hz}$, Tab.1) and $1.746 \mathrm{~s}(0.573 \mathrm{~Hz}, \mathrm{Tab} .2)$. 

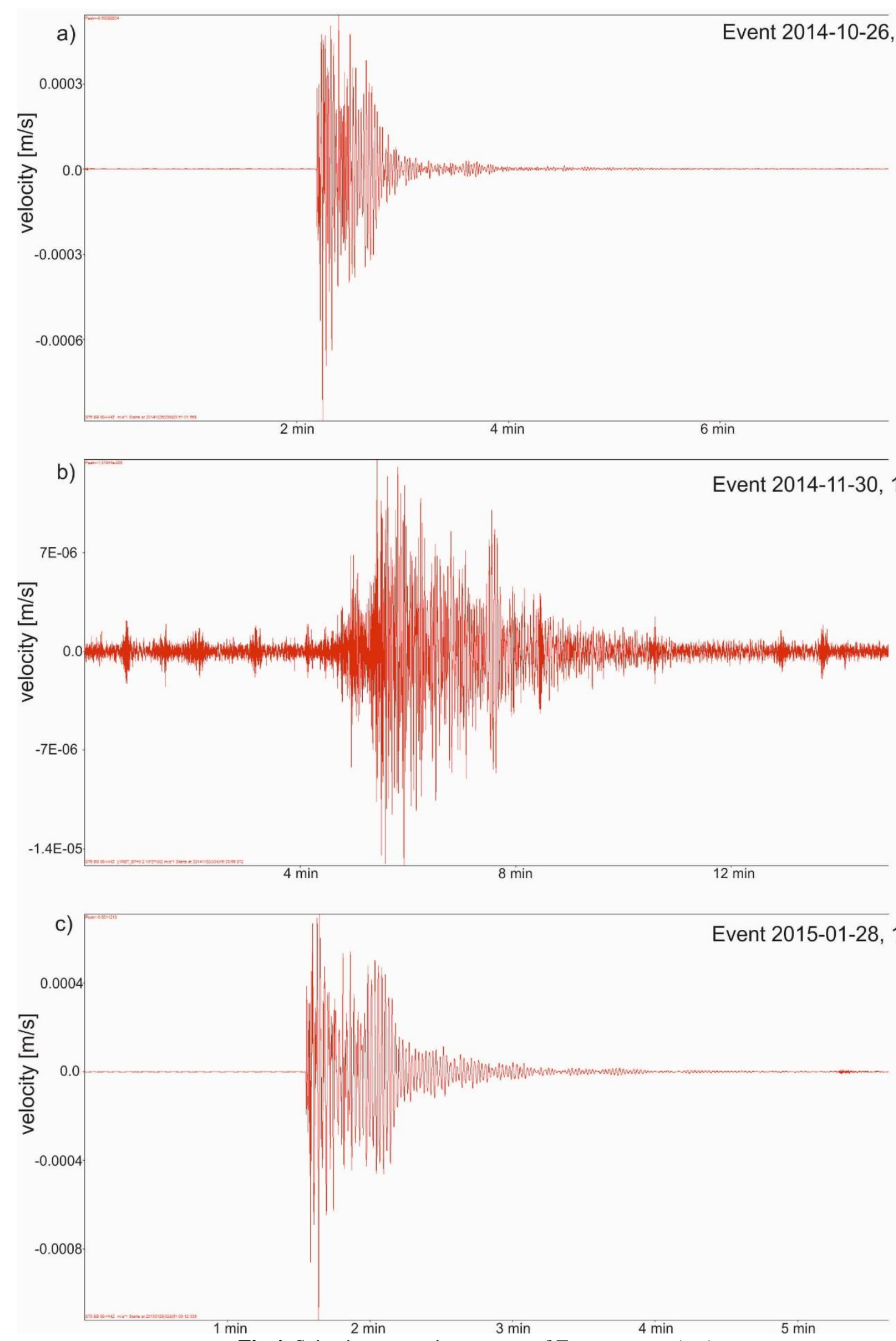

Fig.4. Seismic event seismograms of Z-component (a-c). 
Tab.1. Observed maxima on HVSRN spectrum.

\begin{tabular}{cccc|ccc}
\hline \multirow{2}{*}{ Noise record date } & \multicolumn{3}{c}{ Peak } & \multicolumn{3}{c}{ Trough } \\
& $\mathrm{T}_{0}[\mathrm{~s}]$ & $\mathrm{f}_{0}[\mathrm{~Hz}]$ & $\mathrm{H} / \mathrm{V}$ & $\mathrm{T}_{0}[\mathrm{~s}]$ & $\mathrm{f}_{0}[\mathrm{~Hz}]$ & $\mathrm{H} / \mathrm{V}$ \\
\hline $2014-09-07$ & 3.85 & 0.26 & 6.6 & 1.52 & 0.66 & 0.69 \\
$2014-11-06$ & 3.85 & 0.26 & 6.9 & 1.19 & 0.84 & 0.80 \\
$2014-12-15$ & 3.85 & 0.26 & 6.0 & 1.52 & 0.66 & 0.79 \\
$2015-04-01$ & 3.57 & 0.28 & 5.3 & 1.56 & 0.64 & 0.67 \\
Average & $\mathbf{3 . 7 8}$ & $\mathbf{0 . 2 7}$ & $\mathbf{6 . 2}$ & $\mathbf{1 . 4 5}$ & $\mathbf{0 . 7 0}$ & $\mathbf{0 . 7 4}$ \\
\hline
\end{tabular}

Tab.2. Observed maxima on HVSR spectrum.

\begin{tabular}{cccc|ccc}
\hline \multirow{2}{*}{ Event date } & \multicolumn{3}{c}{ Peak } & \multicolumn{3}{c}{ Trough } \\
& $\mathrm{T}_{0}[\mathrm{~s}]$ & $\mathrm{f}_{0}[\mathrm{~Hz}]$ & $\mathrm{H} / \mathrm{V}$ & $\mathrm{T}_{0}[\mathrm{~s}]$ & $\mathrm{f}_{0}[\mathrm{~Hz}]$ & $\mathrm{H} / \mathrm{V}$ \\
\hline $2014-10-26$ & 4.167 & 0.24 & 4.27 & 1.786 & 0.56 & 0.365 \\
$2014-11-30$ & 4.167 & 0.24 & 14.42 & 1.786 & 0.56 & 0.745 \\
$2015-01-28$ & 3.572 & 0.28 & 8.26 & 1.667 & 0.60 & 0.425 \\
Average & $\mathbf{3 . 9 6 9}$ & $\mathbf{0 . 2 5}$ & $\mathbf{8 . 9 8}$ & $\mathbf{1 . 7 4 6}$ & $\mathbf{0 . 5 7}$ & $\mathbf{0 . 5}$ \\
\hline
\end{tabular}

HVSRN and HVSR curves
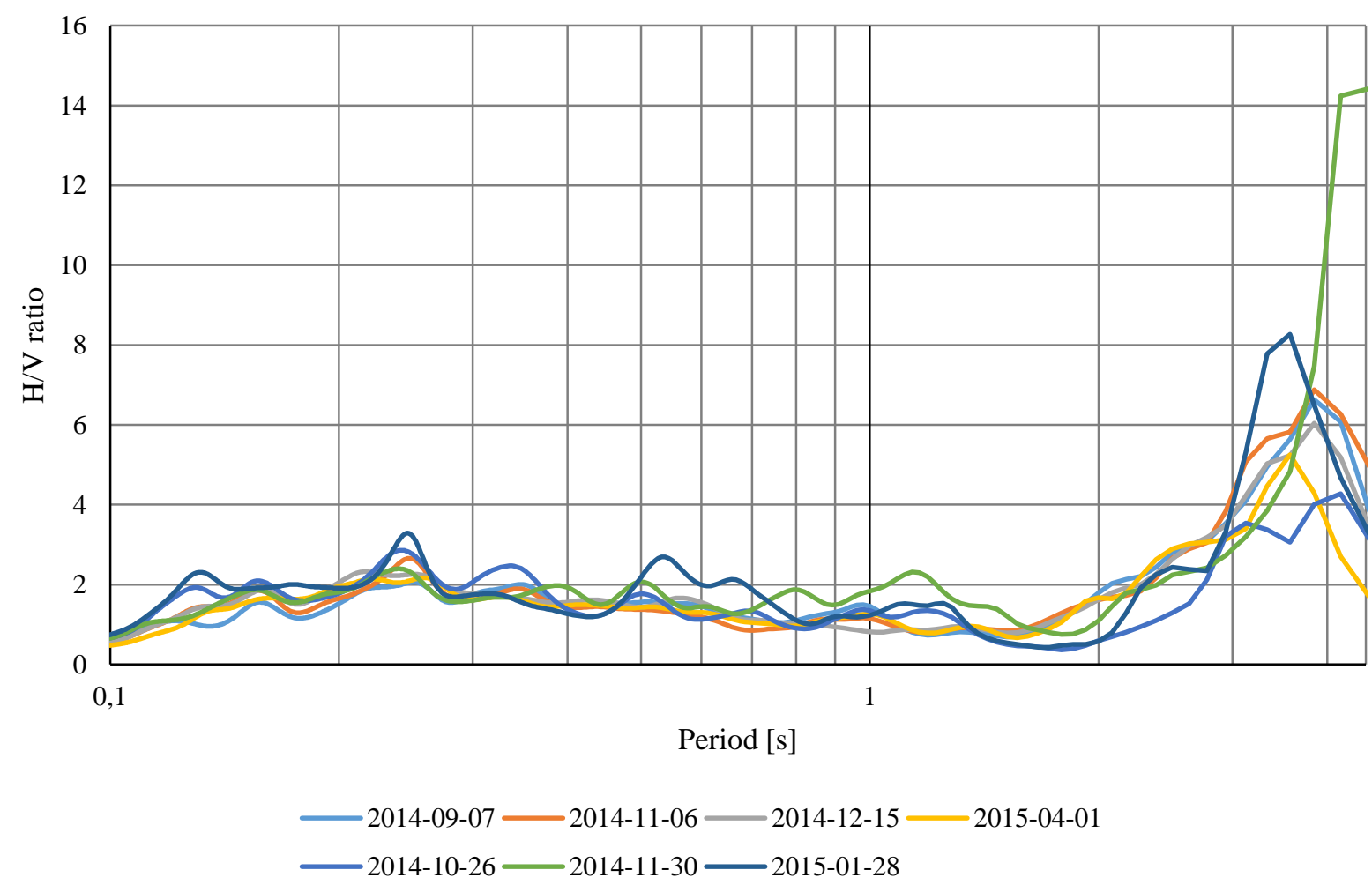

Fig.5. The HVSRN (2014-09-07, 2014-11-06, 2014-12-15 and 2015-04-01) and HVSR (2014-10-26, 2014-1130 and 2015-01-28) results.

These results indicated that period/frequency difference between first maximum and next minimum varied from 0.38 times to 0.44 times (Tab.3) what showed that the gap between "positive and negative peaks" is almost half value of resonance period. It seemed interesting that the $\mathrm{H} / \mathrm{V}$ ratios between maximum and minimum reached 17.6 times for 
HVSR method and 8.4 for HVSR method (Tab.3) what showed that peak to trough ratio for HVSR is almost double value of HVSRN peak to trough ratio.

\section{Discussion and conclusions}

The observed maximum was interpreted as the fundamental resonance period in the relative long-period band that corresponds to a deeper interface of high impedance contrast (Oros 2009). The shorter resonance periods are represented as a set of peaks from $0.1 \mathrm{~s}$ to $1.0 \mathrm{~s}$ (rejected by J-SESAME criteria) which were detected by the both HVSR and HVSRN method (Oros 2009). It may be linked to either the occurrence of the first higher mode of Rayleigh waves supplemented by Airy phase (Konno \& Ohmachi 1998), or the presence of another impedance contrast in the upper levels of sediments or the housing foundations, where station is located. The local geology was not well-known, especially the shallow subsurface layers and adequate study is required.

In order to interpret the results we adopted the assumptions presented by Oros (2009) and conclude that the calculated ellipticity (Fig. 5) might be related to the lithological stratification, with the impedance contrast and the velocity gradient resulting from a deep loose Cenozoic sediment layer . Therefore, it can be concluded, according to the three types of particle motion (Konno \& Ohmachi 1998), that the obtained $\mathrm{H} / \mathrm{V}$ fundamental peak represents the motion behavior "situated" between type 1 (retrograde only) and type 2 (impedance contrast larger than 2). In other words, the $H / V$ maximum and corresponding the fundamental resonance frequency in this site probably correlates with the depth of the Cenozoic complex layer
(Quaternary + Tertiary). At thicknesses varying from $370 \mathrm{~m}$ to $390 \mathrm{~m}$ (Lubacha 2005, Miller 2005), the average Vs velocities for the $3.78 \mathrm{~s}$ resonance period are about $400 \mathrm{~m} / \mathrm{s}$ and $420 \mathrm{~m} / \mathrm{s}$ respectively. This is a preliminary interpretation that will require further analysis.

The HVSR and HVSRN methods applied to the same single-station measurements showed maximum peak values for all curves at similar resonance frequencies at $0.25 \mathrm{~Hz}$ and $0.26 \mathrm{~Hz}$, and for minimum (trough) values at $0.57 \mathrm{~Hz}$ or $0.70 \mathrm{~Hz}$. Although, similarities are seen in resonance frequencies, the individual maximum $\mathrm{H} / \mathrm{V}$ peak values differed from each other. The HVSR technique produced relatively higher amplification coefficients than the HVSRN technique. Observed changes in amplification results might confirm the relation presented by Nakamura (1989) and Konno \& Ohmachi (1998):

$$
A_{S}=2.5 \beta R_{M B},
$$

where $A_{s}$ is amplification factor derived from the transfer function of vertically incident $S$ waves (referred to HVSR peak), $R_{M B}$ is peak ratio obtained for microtremor (seismic noise) records, $\beta$ is defined as:

$$
\beta=\frac{H_{R}(f)}{H_{R}(f)+H_{L}(f)},
$$

where $H_{R}(f)$ and $H_{L}(f)$ are horizontal components of Rayleigh and Love waves respectively. Therefore, it can be assumed that HVSRN maxima represent the fundamental mode ratio peak multiplied by $\beta$, and HVSR coda waves peaks are the "true" amplification coefficients.

Tab.3. Comparison of maxima and minima observed in the Fig.5 and set together in Tab.1 and 2.

\begin{tabular}{cccc}
\hline & Parameter & $\mathbf{T}_{\text {trough }} / \mathbf{T}_{\mathbf{1}}$ & $\left(\mathbf{H} / \mathbf{V}_{\text {peak }}\right) /\left(\mathbf{H} / \mathbf{V}_{\text {trough }}\right)$ \\
\hline Ratios & for HVSR & $\mathbf{0 . 4 4}$ & $\mathbf{1 7 . 6}$ \\
$\max /$ min & for HVSRN & $\mathbf{0 . 3 8}$ & $\mathbf{8 . 4}$ \\
\hline
\end{tabular}


Following that, the obtained ratios in Tab.1 can be used to estimate the horizontal component (Rayleigh and Love waves) share, $\beta$, (Tab.4) in the H/V ratios (Konno \& Ohmachi 1998), assuming a constant field of seismic noise:

$\beta=\frac{H V S R}{2.5 H V S R N}$.

Tab.4. Share of horizontal components (Rayleigh and Love wave) in the $\mathrm{H} / \mathrm{V}$ ratios.

\begin{tabular}{ll}
\hline Parameter & H/V \\
\hline HVSR/HVSRN & 1.45 \\
$\beta$ & $\mathbf{0 . 5 8}$ \\
\hline
\end{tabular}

According to a spatial autocorrelation study by Miyadera and Tokimatsu (1992), in the field $\beta$ tends to vary from site to site but lies between 0.3 and 0.5 for fundamental mode Rayleigh waves (Konno \& Ohmachi 1998). The calculated $\beta$ value (Tab. 4) was 0.58 and it can be suggested, comparing them to relation (4), that the Love wave share in surface motion might be insignificant that results in the $\beta$ value increase. The Love wave share remains unknown. Moreover, the authors considered that a large $\beta$ value could also be produced by instrumental and numerical errors, which could have occurred during the survey due to environmental changes (e.g. temperature) and presence of house foundations. Nevertheless, if these errors occurred the obtained resonance frequencies could be appropriate and the amplification coefficients need more considered examination.

\section{References}

Atakan K. (2007). The Need for Standardized Approach for Estimating the Local Site Effects Based on Ambient Noise Recordings, Increasing Seismic Safety by Combining Engineering Technologies and Seismological Data, Springer, 3-15.
Bard P.-Y. (1999). Microtremor measurements: a tool for site effect estimation?, State-ofthe-art paper, [In:] Second International Symposium on the Effects of Surface Geology on seismic motion, Yokohama, December 1-3, 1998, (eds Irikura, Kudo, Okada \& Sasatani), Balkema, 3, 1251-1279.

Bindi D., Marzorati S., Parolai S., Strollo A., Jäckel K. H. (2008). Empirical spectral ratios estimated in two deep sedimentary basins using microseisms recorded by shortperiod seismometers. Geophysical Journal International, 176, 1, 175-184

Bonnefoy-Claudet S., Cotton F., Bard P.-Y. (2006a). The nature of noise wavesfield and its applications for site effects studies. A literature review, Earth-Science Reviews, 79, 205-227.

Bonnefoy-Claudet S., Cornou C., Bard P.-Y., Corron F., Moczo P., Kristek J., Fäh D. (2006b). H/V ratio: a tool for site effects evaluation. Results from 1-D noise simulations. Geophysical Journal International, 167(2), 827-837.

Delgado J., Lopez Casado C., Giner J., Extevez A., Cuenca A., Molina S. (2000). Microtremors as a Geophysical Exploration Tool: Applications and Limitations. Pure and Applied Geophysics, 157, 1445-1462.

Gosar A., Rošer J., Šket Motnikar B., Zupancic B. (2010). Microtremor study of site effects and soil-structure resonance in the city of Ljublana (central Slovenia), Bull Earthquake Eng., 8, 571-592.

Jasiński A. \& Janicki K. (2003). Geologiczne uwarunkowania wpływu składowiska Żelazny Most na wody podziemne (Geological conditions of Żelazny Most landfill impact on groundwater). WUG: Bezpieczeństwo Pracy i Ochrona Środowiska w Górnictwie, 6, 7-10 (in Polish).

Kazimierczyk M. (2002). Parametry drgań powierzchni generowanych wstrząsami górniczymi w Legnicko - Głogowskim Okręgu Miedziowym (The parameters of 
surface vibration generated by mining tremors in the Legnica - Głogów Copper District). Warsztaty z cyklu ,Zagrożenia naturalne w górnictwie", Mat. Symp., 145162 (in Polish).

Konno K. \& Ohmachi T. (1998). Groundmotion characteristics estimated from spectral ratio between horizontal and vertical components of microtremor. Bulletin of the Seismological Society of America, 88, 1, 228-241.

Lermo J. \& Chávez-García F.J. (1993). Site effect evaluation using spectral ratios with only one station. Bulletin of the seismological society of America, 83, 5, 1574-1594.

Lubacha J. (2005) Borehole profile Daniówka (website: http://otworywiertnicze.pgi.gov. $\mathrm{pl} /$ Details/Information/2782339)

Mendecki M.J., Bieta B., \& Mycka, M. (2014). Determination of the resonance frequencythickness relation based on the ambient seismic noise records from Upper Silesia Coal Basin. Contemporary Trends in Geoscience, 3(1), 41-51.

Miller J. (2005) Borehole profile Tarnówek (website: http://otworywiertnicze.pgi.gov. pl/Details/Information/2782324)

Miyadera Y. \& Tokimatsu K. (1992). Sampling of surface waves in short period microtremors. Proc., Ann. Meet. JSSMFE, 965-966 (in Japanese with English abstract).

Nakamura, Y. (1989). A method for dynamic characteristics estimation of subsurface using microtremor on the ground surface. Railway Technical Research Institute, Quarterly Reports, 30, 1, 25-33.

Nakamura Y. (2008). On the H/V Spectrum, The $14^{\text {th }}$ World Conference on Erthquake
Engineering October 12-17, 2008 Beijing, China.

Nogoshi M. \& Igarashi T. (1971). On the Amplitude Characteristics of Microtremor Part 2 (in Japanese with English abstract), Jour. Seism. Soc. Japan, 24, 26-40.

Olszewska D. (2008). Ocena efektów lokalnych i struktury częstotliwościowej sygnałów sejsmometrycznych dla poprawy dokładności prognozy rozprzestrzeniania drgań wzbudzanych wstrząsami górniczymi w Legnicko-Głogowskim Okręgu Miedziowym (Analysis of site effects and frequency spectrum of signals in order to improvement accuracy of attenuation relation of ground motion caused by mining induced seismic events in Legnica Głogow Copper district) Kraków: Akademia Górniczo-Hutnicza im. Stanisława Staszica, ( $\mathrm{PhD}$ Thesis in Polish).

Oros E. (2009). Site effects investigation in the city of Timisoara using spectral ratio methods. Romanian Reports in Physics, 61, 2, 347-358.

SESAME (2003). WP03 - H/V Technique: Data Processing, Report on the Multiplatform H/V Processing Software JSESAME (Online access: 2015-01-10, http://sesame.geopsy.org/Delivrables/D0903_qTexte.pdf).

SESAME (2004). Guidelines for the implementation of the $\mathrm{H} / \mathrm{V}$ spectral ratio technique on ambient vibrations measurements, processing and interpretations. (Online access: 2015-01-10, http://billy.geo.uib.no/pub/seismo/SOFTW ARE/SESAME/USERGUIDELINES/SESAME-HV-UserGuidelines.doc). 